\title{
ANALISIS HUKUM ISLAM TERHADAP PANDANGAN MASYARAKAT DESA SIDOMOJO KRIAN SIDOARJO TENTANG PINJAMAN PADA BANK TITIL DAN RENTENIR
}

\author{
Rizki Khoirun Nisa \\ Luwung Rt 01 Rw 03, Sidomojo Krian Sidoarjo \\ rizkikn@gmail.com
}

\begin{abstract}
This article discusses the analysis of Islamic law on the views of the Muslim community in the village of Sidomojo Krian Sidoarjo regarding loans through moneylenders and credit banks. This research is field research in the town of Sidomojo Krian Sidoarjo and is qualitative. The data collection techniques used were interviews and observations, then analyzed using descriptive analysis methods. From the results of the study, it is known that three loan shark customers and three titil bank customers agree that the law of bank interest is haram because it is the same as usury. However, they still borrow from these two places because of economic needs, and the process of borrowing from these places is more straightforward. The opinion of those who forbid bank interest is following Islamic law. In contrast, their actions of borrowing through moneylenders and bank credit are allowed as long as they are forced to do so as a rule "The condition of dharurah will allow something that was originally prohibited." If the compulsion is lost, then the law returns to its origin, which is haram. Seeing that their economy is not improving after making loans through moneylenders and bank-titil, then they should no longer make loans in these two places or in other areas that apply interest.
\end{abstract}

Keywords: Interest, Moneylenders, Bank Titil, Islamic Law.

Abstrak: Artikel ini membahas tentang analisis hukum Islam terhadap pandangan masyarakat muslim desa Sidomojo Krian Sidoarjo tentang pinjaman melalui rentenir dan bank titil. Penelitian ini adalah penelitian lapangan di desa Sidomojo Krian Sidoarjo dan bersifat kualitatif. Teknik pengumpulan data yang digunakan adalah wawancara dan observasi, selanjutnya dianalisis dengan menggunakan metode analisis deskriptif. Dari hasil penelitian diketahui bahwa tiga nasabah rentenir dan tiga nasabah bank titil sepakat bahwa hukum bunga bank adalah haram karena sama dengan riba. Meskipun demikian mereka tetap meminjam ke dua tempat tersebut karena kebutuhan ekonomi dan meminjam di tempat tersebut prosesnya lebih mudah. Pendapat mereka yang mengharamkan bunga bank telah sesuai dengan hukum Islam, sedangkan tindakan mereka meminjam melalui rentenir dan bank titil diperbolehkan asalkan dalam kondisi terpaksa saja sebagaimana kaidah "Kondisi Dharurah akan memperbolehkan sesuatu yang semula dilarang". Jika keterpaksaan itu hilang maka hukumnya kembali ke asal yaitu haram. Melihat ekonomi mereka yang tidak membaik setelah melakukan pinjaman melalui rentenir dan bank titil,

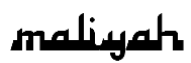

Jurnal Hukum Bisnis Islam

Volume 9, Nomor 01, Juni 2019

p-ISSN: 2088-4869/ e-ISSN: 2597-4351 
Analisis Hukum Islam Terhadap Pandangan Masyarakat ...

maka hendaknya mereka tidak lagi melakukan pinjaman di kedua tempat tersebut atau di tempat lain yang menerapkan bunga.

Kata Kunci: Bunga, Rentenir, Bank Titil, Hukum Islam.

\section{Pendahuluan}

Manusia merupakan makhluk sosial yang tidak bisa terlepas dari kebutuhan. Untuk memenuhi kebutuhannya ia harus melakukan upaya-upaya agar tetap bisa bertahan hidup, upaya atau usaha tersebut sering dikenal dengan kegiatan ekonomi. Kegiatan ekonomi adalah kegiatan yang dilakukan manusia untuk memperoleh barang dan jasa agar tercapai kemakmuran dalam hidupnya. Kegiatan ekonomi ini bisa dalam bentuk bertani, berkebun, berdagang dan lain-lain. Dalam kegiatan ekonomi tidak jarang ditemui sebuah hambatan salah satunya adalah hambatan dalam aspek permodalan.

Dari masalah permodalan ditemukan banyak solusi, salah satunya pinjaman produktif. Pinjaman produktif adalah pinjaman yang diambil seseorang tidak untuk dipakai melainkan untuk modal usaha, ia menanam dan mengembangkannya. ${ }^{1}$ Pinjaman permodalan ini banyak disediakan oleh pihak swasta.

Selain pinjaman produktif ada pula pinjaman konsumtif. Pinjaman konsumtif adalah pinjaman yang diambil debitur untuk memenuhi kebutuhan hidupnya. ${ }^{2}$ Pinjaman konsumtif ini biasanya disediakan oleh bank titil dan rentenir, pinjaman konsumtif sama seperti pinjaman produktif yaitu sama-sama mengandung bunga dalam operasionalnya. ${ }^{3}$

Penerapan sistem bunga ini biasanya telah disepakati pada awal perjanjian pinjaman. Pada awal transaksi, pemberi pinjaman berasumsi bahwa nasabah pasti mendapat laba atas usahanya, mereka tidak mau tahu apakah konsumen

1 Murtadha Muthahhari, Pandangan Islam Tentang Asuransi Dan Riba (Bandung: Pustaka Hidayah, 1995), 45.

${ }^{2}$ Ibid.

3 Dahlan Siamat, Manajemen Lembaga Keuangan (Jakarta: CV Intermedia, 1995), 456. 
mengalami kerugian, yang mereka tahu konsumen harus membayarkan angsuran serta bunganya tiap bulan tanpa melihat situasi yang dialami oleh konsumen.

Di Desa Sidomojo terdapat beberapa kegiatan ekonomi yang mencakup kegiatan utang piutang yang mengandung bunga diantaranya rentenir dan bank titil. Rentenir dan bank titil biasanya menawarkan jasa mereka dari pintu ke pintu dengan menggunakan persyaratan yang mudah, bahkan tidak ada persyaratan, sehingga menarik minat masyarakat agar mau meminjam uang ke rentenir dan bank titil. Pinjaman yang disediakan bank titil dan rentenir bebas digunakan sesuai keinginan peminjam, bisa digunakan untuk keperluan produksi maupun konsumsi, mudah pada awal peminjaman namun pada saat pengembalian peminjam mengalami kesulitan. ${ }^{4}$

Di Desa Sidomojo Krian Sidoarjo mayoritas penduduknya beragama Islam. Bunga dalam agama Islam merupakan sesuatu yang bersifat haram, maka seharusnya masyarakat tidak menggunakan pinjaman yang mengandung bunga, namun Masyarakat muslim di Desa Sidomojo masih menggunakan pinjaman yang menerapkan bunga.

Berdasarkan fenomena di atas, penulis terdorong untuk menganalisis pendapat masyarakat mengenai pinjaman pada rentenir dan bank titil di Desa Sidomojo.

Berdasarkan penelusuran kajian kepustakaan yang penulis lakukan, berikut ada beberapa penelitian yang terkait dengan permasalahan yang ada dalam penelitian ini di antaranya: Skripsi Evy Hidayatur Rohmah yang berjudul "Analisis Persepsi Dan Minat Masyarakat Terhadap Produk talangan Haji Perbankan Syariah (Studi Kasus Kecamatan Panceng)"5, skripsi Aidi Sugiarto yang berjudul "Fatwa MUI Tentang Bunga Bank (Studi terhadap Pandangan Masyarakat

\footnotetext{
${ }^{4}$ Sri Wahyuni, "Nasabah Rentenir," Wawancara, October 11, 2013.

${ }^{5}$ Evy Hidayatur Rohmah, "Analisis Persepsi Dan Minat Masyarakat Terhadap Produk Talangan Haji Perbankan Syariah (Study Kasus Kecamatan Panceng)" (UIN Sunan Ampel Surabaya, 2013).
} 
Mlagi)" "dan skripsi Wahyu Ikhwan yang berjudul "Riba dan Bunga Bank Perspektif Moh. Hatta"7. Berbeda dengan penelitian sebelumnya, penelitian ini fokus pembahasannya terletak pada persepsi dan kegiatan ekonomi masyarakat yang dianalisis menggunakan deskripsi analitis.

Penelitian ini merupakan penelitian lapangan (field research), yang dilakukan di Desa Sidomojo Krian Sidoarjo. Penulis memilih lokasi ini karena di desa tersebut mayoritas masyarakatnya beragama Islam, dimana dalam agama Islam bunga hukumnya haram tapi di Desa tersebut masih banyak kegiatan ekonomi yang mengandung bunga.

Pengumpulan data dilakukan melalui observasi dan wawancara kepada karyawan dan nasabah rentenir dan bank titil. Data yang telah berhasil dikumpulkan selanjutnya akan dianalisis secara deskriptif analitis dengan pola pikir induktif.

\section{Konsep Bunga Bank di dalam Hukum Islam}

Bunga dalam kegiatannya banyak mengandung berbagai keburukan di antaranya:

1. Bunga menimbulkan permusuhan dan kebencian antar individu dan masyarakat serta menumbuh kembangkan fitnah dan terputusnya jalinan persaudaraan.

2. Masyarakat yang berinteraksi dengan bunga adalah masyarakat yang miskin, tidak memiliki rasa simpatik. Mereka tidak akan saling tolong menolong dan membantu sesama manusia kecuali ada keinginan tertentu yang tersembunyi di balik bantuan yang mereka berikan. Masyarakat seperti ini tidak akan pernah merasakan kesejahteraan dan ketenangan. Bahkan kekacauan dan kesenjangan akan senantiasa terjadi di setiap saat.

\footnotetext{
${ }^{6}$ Aidi Sugiarto, "Fatwa MUI Tentang Bunga Bank (Studi Terhadap Masyarakat Malgi)" (UIN Sunan Kalijaga Yogyakarta, 2008).

${ }^{7}$ Wahyu Ikhwan, "Riba Dan Bunga Bank Perspektif Moh Hatta" (UIN Sunan Kalijaga Yogyakarta, 2010).
} 
3. Perbuatan bunga mengarahkan ekonomi ke arah yang menyimpang dan hal tersebut mengakibatkan pemborosan. ${ }^{8}$

Meskipun banyak mengandung hal-hal yang negatif, pada kenyataannya sampai sekarang praktek riba yaitu bunga tetap tumbuh subur dalam perekonomian. Sehingga haramnya riba tersebut harus dipertegas lagi dengan fatwa tentang bunga adalah haram, yang dikeluarkan baik oleh ulama Indonesia maupun ulama-ulama Islam di negara-negara muslim lainnya. Lajnah Bahsul Masa'il NU, Bandar Lampung terdapat tiga pendapat ulama sehubungan dengan masalah bunga antara lain adalah:

1. Haram, sebab termasuk utang yang dipungut rentenir.

2. Halal, sebab tidak ada syarat pada waktu akad, sedangkan adat yang berlaku tidak dapat begitu saja dijadikan syarat.

3. Subhat, sebab para ahli hukum berselisih pendapat tentangnya.9

Meskipun ada perbedaan pandangan, Lajnah memutuskan bahwa (pilihan) yang lebih berhati-hati ialah pendapat pertama, yakni menyebut bunga adalah haram.

Majlis Tarjih Muhammadiyah dalam Muktamar di Sidoarjo (1968) memutuskan, antara lain:

1. Bunga hukumnya haram dengan nash sharih al-Qur'an dan as-Sunnah.

2. Bank dengan sistem bunga hukumnya haram dan bank tanpa bunga hukumnya halal.10

\section{Gambaran Umum Desa Sidomojo Krian Sidoarjo}

Desa Sidomojo Krian Sidoarjo merupakan Desa yang penulis teliti sebagai obyek pada penelitian ini. Desa Sidomojo merupakan satu diantara beberapa Desa yang terletak di

8 Muhammad Nur Ichwan Muslim, "Riba Dan Dampaknya," n.d., http://muslim.or.id/fiqh-dan-muamalah/riba-dan-dampaknya-2.html/commentpage-2, di akses pada hari selasa tanggal 22 oktober 2013, pukul13:12.

${ }^{9}$ Muhammad Nafik H.R, Benarkah Bunga Haram? (Surabaya: Amanah Pustaka, 2009), 113.

${ }^{10}$ Ibid, 115. 
Kecamatan Krian. Desa Sidomojo terdiri dari 3 dusun yaitu dusun Luwung, Tundungan dan Mojokemuning, serta terdiri dari 13 Rukun Tetangga (RT) dan 3 Rukun Warga (RW).

Adapun batas-batas wilayah Desa Sidomojo adalah sebagai berikut:

\section{Sebelah Utara :Desa Watu Golong}

Sebelah Selatan:Desa kemera'an

Sebelah Timur :Desa kemasan

Sebelah Barat :Desa Sidomulyo

Jumlah penduduk desa Sidomojo adalah 3.655 (tiga ribu enam ratus lima puluh lima) orang jiwa terdiri dari 847 (delapan ratus empat puluh tujuh) kepala keluarga (KK). Komposisi jumlah penduduk berdasarkan jenis kelamin adalah laki-laki 1.810 (seribu delapan ratus sepuluh) jiwa dan perempuan 1.845 (seribu delapan ratus empat puluh lima) jiwa. Sedangkan menurut keyakinan adalah agama Islam 3.647 jiwa dan agama Kristen 8 jiwa. ${ }^{11}$

Kegiatan ekonomi merupakan suatu usaha yang dilakukan masyarakat untuk memenuhi kebutuhan hidupnya, mayoritas penduduk Sidomojo beRprofesi sebagai pedagang (membuka usaha sendiri) atau wiraswasta. Sebagian masyarakat yang lain beRprofesi sebagai ABRI (Angkatan Bersenjata Republik Indonesia), PNS (Pegawai Negeri Sipil), pegawai swasta, petani, pertukangan. 12

Dalam melakukan kegiatan wirausaha maupun dalam memenuhi kebutuhan hidup sehari-hari tidak jarang warga Sidomojo mengalami sebuah hambatan salah satunya hambatan dalam aspek keuangan, hambatan tersebut banyak menarik perhatian pihak lain untuk membantu masyarakat dalam mengatasi permasalahannya, sehingga terdapat berbagai macam pilihan pinjaman yang membantu masyarakat dalam mengatasi masalah keuangan, berikut deskripsi mengenai pihak pemberi pinjaman dan persepsi nasabah penguna pinjaman tersebut

11 “Data Monografi Desa Sidomojo Krian Sidoarjo Tahun 2013,” 2013.

12 Ibid. 


\section{Praktik Pinjaman pada Rentenir di Desa Sidomojo Krian Sidoarjo}

Rentenir merupakan seseorang yang mencari nafkah dengan cara membungakan pinjaman, rentenir ini menawarkan jasanya dari pintu ke pintu dengan alasan membantu masyarakat dalam mengatasi masalah perekonomian, namun mengatasi masalah perekonomian bukanlah tujuan utama rentenir dalam memberikan pinjaman, tujuan utama rentenir adalah mencari keuntungan dari kesulitan ekonomi yang dialami oleh masyarakat dengan cara penerapan bunga yang begitu besar yaitu $10 \%$ dalam jangka waktu 10 minggu. ${ }^{13}$

Berikut nasabah yang melakukan pinjaman ke rentenir:

1. Bu Sri, ibu rumah tangga

$\mathrm{Bu}$ Sri merupakan seorang ibu rumah tangga yang mengalami permasalahan ekonomi, pengeluaran yang ada lebih besar dari pemasukan yang diterima oleh Bu Sri dan suaminya. Untuk mengatasi permasalahan perekonomian tersebut $\mathrm{Bu}$ Sri teRpaksa untuk meminjam uang kepada rentenir, alasan $\mathrm{Bu}$ Sri meminjam uang kepada rentenir karena rentenir menawarkan jasanya langsung sehingga $\mathrm{Bu}$ Sri tidak perlu repot-repot mencari pinjaman lagi dan pengajuan pinjaman kepada rentenir tersebut tanpa ada syarat khusus serta tidak ada jaminan.

Pada awal peminjaman Bu Sri memang merasa terbantu dengan adanya pinjaman dari rentenir, namun setelah menjadi nasabah rentenir Bu Sri mulai terbebani karena harus membayar angsuran dan bunga yang besar tiap minggunya. Setelah melakukan pinjaman kepada rentenir ini $\mathrm{Bu}$ Sri merasa perekonomiannya memburuk. Bu Sri kurang setuju dengan adanya bunga yang diterapkan rentenir karena persentasenya yang terlalu besar.

${ }^{13}$ Wahyuni, "Nasabah Rentenir." 
Menurut pandangan $\mathrm{Bu} \mathrm{Sri}$, bunga yang ada pada pinjaman yang disediakan oleh rentenir dalam agama Islam tidak diperbolehkan karena termasuk dalam kategori riba. ${ }^{14}$

2. Bu Susi, pemilik toko kelontong

Permintaan barang banyak tetapi modal usaha yang ada tidak cukup untuk memenuhi permintaan konsumen, bila menunggu pencairan pinjaman yang cukup lama maka konsumen akan pergi, demikian alasan Bu Susi memilih jasa pinjaman yang ada pada rentenir, karena pinjaman yang disediakan rentenir praktis dan mudah.

Bu Susi tidak keberatan terhadap bunga yang diterapkan oleh rentenir, karena dengan cara yang mudah maka wajar bunga yang diterapkan tinggi. Walau beliau setuju dengan bunga yang ada dalam rentenir, tetapi beliau merasa terbebani atas bunga yang diterapkan dan menurut beliau bunga yang ada pada rentenir ini tidak diperbolehkan karena merugikan nasabahnya.

Setelah menjadi nasabah rentenir perkembangan yang dirasa adalah jumlah dan variasi dagangan yang semakin banyak, tetapi bila dilihat dari segi ekonomi beliau merasa tidak ada perkembangan, karena hasil dan laba dari penjualan digunakan untuk membayar angsuran pada rentenir. ${ }^{15}$

3. Bu Sum, ibu rumah tangga, Tundungan

Bu Sum merupakan ibu rumah tangga yang mempunyai masalah ekonomi, karena beliau bukan penduduk asli Desa Sidomojo, maka beliau tidak bisa meminjam uang kepada lembaga yang bersifat legal, pinjaman dari tetangga juga tidak berhasil beliau dapatkan, maka menurut beliau jalan yang paling tepat untuk menyelesaikan permasalahan tersebut adalah dengan cara meminjam uang kepada rentenir.

Sebenarnya beliau tidak setuju dengan bunga yang diterapkan oleh pihak rentenir karena bunganya terlalu

\footnotetext{
${ }^{14}$ Wahyuni.

${ }^{15}$ Susi, "Nasabah Rentenir," Wawancara, December 4, 2013.
} 
besar. Menurut beliau bunga yang ada pada rentenir tidak diperbolehkan dalam agama Islam karena merugikan nasabahnya. Setelah melakukan pinjaman kepada rentenir ini Bu Sumiati merasa perekonomiannya memburuk, karena hutangnya yang semakin bertambah. ${ }^{16}$

Dari tiga nasabah rentenir, dua orang menggunakan pinjaman rentenir untuk kebutuhan konsumtif dan satu orang lainnya menggunakan untuk kebutuhan produktif. Dari tiga orang nasabah, dua orang nasabah tidak setuju dan satu orang setuju dengan penerapan bunga yang ada pada rentenir. Jika dilihat dari segi agama Islam menurut tiga orang nasabah tersebut bunga yang ada pada rentenir tidak diperbolehkan, dan ketiga nasabah rentenir perekonomiannya menjadi memburuk.

\section{Praktik Peminjaman di Bank Titil di Desa Sidomojo Krian Sidoarjo}

Bank titil merupakan sebutan yang diberikan masyarakat kepada lembaga jasa keuangan swasta yang memberi pinjaman kepada masyarakat dengan bunga yang cukup besar. Bank titil yang beroperasi di desa Sidomojo ini sebenarnya bukan bank tapi sebuah koperasi yaitu koperasi Usaha Bersama (UB). Titil berasal dari bahasa Jawa yang artinya mengambil sedikit demi sedikit, bank titil juga dikenal dengan bank minggonan karena petugas bank titil yang mengambil uang nasabahnya tiap minggu. ${ }^{17}$ Sistem kerja bank titil ini hampir sama dengan rentenir, yang membedakan hanyalah rentenir berbentuk perseorangan sedangkan bank titil merupakan penyedia pinjaman dalam bentuk lembaga. Sama seperti rentenir, bank titil juga menawarkan jasa dari pintu ke pintu tanpa menggunakan persyaratan, kemudahan pengajuan pinjaman tersebut membuat masyarakat tertarik untuk menjadi nasabah bank titil .

\footnotetext{
${ }^{16}$ Sum, "Nasabah Rentenir," Wawancara, November 23, 2013.

17 Tum, "Nasabah Bank Titil," Wawancara, November 27, 2013.
} 
Persyaratan menjadi nasabah bank titil warga cukup menyerahkan foto kopi KTP, pinjaman tidak menggunakanbarang jaminan. Bunga yang digunakan oleh bank titil ini yaitu $13 \%$ perminggu, dengan masa pelunasan selama 10 minggu. ${ }^{18}$

Berikut nasabah yang meminjam ke bank titil:

1. Bu Tum, ibu rumah tangga, Tundungan

Masalah ekonomi tidak bisa terlepas dari kehidupan $\mathrm{Bu}$ Tum, beliau adalah ibu rumah tangga biasa sedangkan suaminya bekerja sebagai buruh bangunan yang penghasilannya tidak bisa diharapkan, terkadang ada pekerjaan terkadang tidak, sedangkan kebutuhan hidup sehari-hari tidak bisa ditunda terlebih lagi untuk membayar biaya sekolah kedua anaknya.

Untuk memenuhi kebutuhan tersebut $\mathrm{Bu}$ Tum terpaksa meminjam uang kepada bank minggonan atau yang lebih dikenal bank titil, $\mathrm{Bu}$ Tum mengenal bank titil dari temannya yang juga menggunakan jasa bank titil, beliau menggunakanjasa bank titil karena cara pengajuan pinjaman yang mudah yaitu dengan cara penyerahan foto kopi KTP.

Menurut $\mathrm{Bu}$ Tum penerapan bunga yang ada pada bank titil terlalu besar, bila dilihat dari perspektif Islam bunga yang ada pada bank titil ini tidak diperbolehkan karena merugikan peminjam serta semakin mempersulit perekonomian nasabahnya.

Setelah menjadi nasabah bank titil $\mathrm{Bu}$ Tum merasa perekonomiannya memburuk, pemasukan dalam keluarga sudah tidak ada karena $\mathrm{Bu}$ Tum dan suaminya sudah tidak berkerja, kebutuhan sehari-hari hanya mengandalkan pemberian dari anaknya yang sudah berkerja, kini beban $\mathrm{Bu}$ Tum ditambah dengan pinjaman dan bunga yang besar. Pinjaman yang awalnya digunakan untuk membayar biaya pendidikan kedua anaknya justru sekarang pinjaman tersebut membuat bertambahnya tunggakan biaya sekolah

${ }^{18}$ A, "Karyawan Bank Titil," Wawancara, November 23, 2013. 
kedua anaknya, karena uang yang diperoleh terpaksa dibayarkan kepada bank titil. ${ }^{19}$

2. Bu Anik, ibu rumah tangga, Tundungan

$\mathrm{Bu}$ Anik menggunakan jasa bank titil untuk memenuhi kebutuhan hidup sehari-hari. Beliau menggunakan jasa bank titil karena caranya yang praktis serta pencairan dananya yang cepat.

$\mathrm{Bu}$ Anik setuju dengan bunga yang telah diterapkan oleh bank titil, karena bunga tersebut merupakan imbalan atas pinjaman yang telah diberikan. Sedangkan menurut Bu Anik bila dilihat dari pandangan agama Islam bunga yang ada pada bank titil ini boleh diterapkan, karena dari awal sudah ada kesepakatan dari kedua belah pihak, dan apapun yang terjadi setelah melakukan pinjaman sudah menjadi resiko si peminjam. Setelah menjadi nasabah bank thi-til ini Bu Anik merasa terbantu karena pinjaman tersebut digunakan untuk kebutuhan yang tidak bisa ditunda pada waktu itu, tetapi perekonomian $\mathrm{Bu}$ Anik tidak mengalami perkembangan, sama seperti sebelum menjadi nasabah bank titil. ${ }^{20}$

3. Bu Warti, ibu rumah tangga, Tundungan

$\mathrm{Bu}$ Warti merupakan warga Madiun yang merantau ke Sidomojo, karena suami beliau bekerja di salah satu pabrik yang berada disekitar Sidomojo, saat ini $\mathrm{Bu}$ Warti dan keluarga tinggal di salah satu kontrakan yang ada di Dusun Tundungan.

Terkadang dalam memenuhi kebutuhan ekonomi $\mathrm{Bu}$ Warti dan keluarga mengalami sebuah hambatan, karena beliau bukan penduduk asli desa Sidomojo beliau tidak bisa meminjam uang kepada lembaga yang bersifat legal, pinjaman dari tetangga juga tidak berhasil beliau dapatkan, maka menurut beliau jalan yang paling tepat untuk menyelesaikan permasalahan tersebut adalah dengan cara meminjam uang kepada bank titil. Bu Warti mengetahui adanya pinjaman jasa bank titil dari temannya, dan Bu Warti

19 Tum, "Nasabah Bank Titil."

${ }^{20}$ Anik, "Nasabah Bank Titil," Wawancara, October 27, 2013. 
merasa tertarik menjadi nasabah bank titil karena caranya yang praktis dan karena tidak ada jaminan.

$\mathrm{Bu}$ Warti kurang setuju terhadap bunga yang ada pada bank titil karena bungannya yang terlalu besar dan menurut $\mathrm{Bu}$ Warti bila dilihat dari pandangan Islam bunga yang ada pada bank titil ini tidak diperbolehkan karena tidak sesuai dengan ekonomi Islam.

Pinjaman bank titil hanya membantu perekonomian $\mathrm{Bu}$ Warti untuk sementara saja, namun dampak dari pinjaman tersebut membuat perekonomian $\mathrm{Bu}$ Warti memburuk karena hutangnya yang bertambah. ${ }^{21}$

Tiga nasabah bank titil menggunakan pinjaman untuk kebutuhan konsumsi, dan dari tiga nasabah bank titil tersebut mereka tidak setuju dengan bunga yang ada pada bank titil dan dilihat dari agama Islam bunga tersebut tidak diperbolehkan. Dari segi ekonomi ketiga nasabah bank titil menurun karena pinjaman tersebut digunakan untuk kebutuhan konsumsi.

\section{Analisis Hukum Islam terhadap Pandangan Masyarakat Desa Sidomoro Krian Sidoarjo terhadap Pinjaman melalui Rentenir dan Bank Titil}

Masalah ekonomi yang dihadapi masyarakat menjadikan jasa peminjaman muncul dan berkembang di lingkungan masyarakat. Peminjaman tersebut mayoritas tidak diberikan secara Cuma-Cuma, tetapi peminjam harus memberikan dana tambahan atas pinjaman yang diterima yang dikenal dengan bunga. Hal tersebut juga terjadi di desa Sidomojo Krian Sidoarjo.

Meskipun MUI dalam fatwanya mengharamkan bunga pinjaman, masih banyak masyarakat yang masih menggunakan pinjaman meskipun menerapkan sistem bunga. Hal tersebut karena adanya kebutuhan ekonomi dan adanya persepsi yang berbeda di masyarakat bahwa ada yang berpandanga bunga

${ }^{21}$ Warti, "Nasabah Bank Titil," Wawancara, November 27, 2013. 
diperbolehkan dan ada yang menganggap bunga hukumnya haram.

Pandangan tersebut dipengaruhi oleh lingkungan, sebagaimana anggapan masyarakat yang membolehkan bunga karena menganggap bunga sudah menjadi tradisi pada kegiatan ekonomi dan bunga dianggap berbeda dengan riba. Sedangkan yang mengharamkan bunga, menganggap bahwa bunga sama dengan riba.

Berdasarkan hasil wawancara di bank titil, diketahui bahwa tiga nasabah bank titil menggunakan pinjaman untuk kebutuhan konsumsi, dan dari tiga nasabah bank titil tersebut mereka tidak setuju dengan bunga yang ada pada bank titil dan dilihat dari agama Islam bunga tersebut tidak diperbolehkan. Dari segi ekonomi ketiga nasabah bank titil menurun karena pinjaman tersebut digunakan untuk kebutuhan konsumsi.

Berdasarkan wawancara dengan tiga nasabah rentenir, diketahui bahwa dua orang menggunakan pinjaman rentenir untuk kebutuhan konsumtif dan satu orang lainnya menggunakan untuk kebutuhan produktif. Dari tiga orang nasabah, dua orang nasabah tidak setuju dan satu orang setuju dengan penerapan bunga yang ada pada rentenir. Jika dilihat dari segi agama Islam menurut tiga orang nasabah tersebut bunga yang ada pada rentenir hukumnya tidak diperbolehkan, dan ketiga nasabah rentenir perekonomiannya menjadi memburuk.

Berdasarkan data di atas diketahui bahwa nasabah rentenir dan bank titil sepakat bahwa hukum bunga pinjaman adalah haram. Hal tersebut sesuai dengan hukum Islam yang mengharamkan riba sebagaimana firman Allah yang terdapat di Qs. Al-Baqarah: 278

"Hai orang-orang yang beriman, bertakwalah kepada Allah dan tinggalkan sisa Riba (yang belum dipungut) jika kamu orang-orang yang beriman." 22

22 Ibid., 47. 
Riba atau bunga dilarang di dalam agama Islam karena bunga memiliki unsur mendzalimi. Keharaman bunga juga didukung oleh keputusan fatwa Majelis Ulama Indonesia Nomor 1 Tahun 2004 Tentang Bunga, memutuskan hukum bunga (interest):

1. Praktik pembungaan uang saat ini telah memenuhi kriteria riba yang terjadi pada masa Rasulullah SAW, yaitu riba nasi'ah. Dengan demikian, praktik pembungaan uang ini termasuk salah satu bentuk riba, dan riba haram hukumnya.

2. Praktik penggunaan tersebut hukumnya adalah haram, baik dilakukan oleh bank, asuransi, pasar modal, pegadaian, koperasi, dan lembaga keuangan lainnya maupun dilakukan oleh individu. ${ }^{23}$

Meskipun masyarakat yang menjadi nasabah rentenir dan bank titil mengharamkan bunga, namun mereka tetap meminjam ke rentenir dan bank titil karena ingin memenuhi kebutuhan ekonomi baik yang bersifat produktif dan konsumtif. Selain itu, mereka menganggap prosedur pinjaman di rentenir dan bank titil lebih udah dibanding meminjam di tempat lain. Efek dari praktik tersebut, mereka merasa ekonominya menjadi semakin buruk karena harus mencicil pinjaman dan bunganya setiap minggunya.

Berdasarkan dengan kegunaan pinjaman berbunga, jika pinjaman tersebut untuk kegiatan ekonomi produktif terdapat beberapa pendapat yang membolehkannya di antaranya Hasan yang membolehkan bunga produktif, yaitu bunga yang diambil dari nasabah yang berhutang untuk kebutuhan suatu produksi atau usaha.

Hal tersebut juga didukung oleh teori konvensional yang dikutip oleh Ismail dalam bukunya mengenai pembolehan bunga dalam kegiatan produktif, yaitu sebagai suatu properti dari modal, sehingga pihak memberi pinjaman dapat mengambil bunga sebagai imbalan atas dana yang digunakan oleh peminjam secara produktif. Teori ini menganggap uang

23 Abu Muhammad Dwiono Koesen Al-Jambi, Selamat Tinggal Bank Konvensional (Jakarta: Tifa Publishing House, 2013), 111. 
digunakan sebagai modal untuk memproduksi barang. Uang juga memiliki kekuatan sebagai alat untuk memproduksi barang yang lebih banyak dan dengan nilai yang lebih tinggi. Dengan meningkatkan produktivitas, maka keuntungan akan bertambah, sehingga pihak pemberi pinjaman membebankan bunga atas keuntungan dari dana yang dipinjamkan. ${ }^{24}$ Kreditor memberikan waktu kepada debitur untuk menjalankan usahanya agar memperoleh keuntungan. Dengan demikian, maka bunga boleh diberikan sebagai pembagian hasil atas usaha debitur. ${ }^{25}$

Adanya bunga yang terdapat dalam kegiatan produktif seharusnya tidak diperbolehkan, karenakan usaha yang dijalankan tidak selalu menghasilkan keuntungan yang besar untuk membayarkan bunga. Hal itu sesuai dengan teori yang membantah mengenai bunga yang seharusnya tidak diperbolehkan dalam kegiatan ekonomi, alasan tidak diperbolehkannya bunga dalam kegiatan produksi menurut Ismail yaitu peminjam belum tentu menggunakan uang pinjamannya untuk memproduksi barang maupun meningkatkan fungsi barang menjadi nilai yang lebih tinggi. Dengan demikian, maka pembebanan bunga tidak dapat digunakan sebagai alasan untuk diperbolehkannya bunga. Bunga tidak diperbolehkan, tetap menggunakan pinjaman

Menurut sebagian nasabah pengguna pinjaman di Desa Sidomojo, bunga tidak diperbolehkan, namun karena kondisi ekonomi mereka yang mendesak serta semua jasa peminjaman menggunakan bunga, maka mereka terpaksa menggunakan pinjaman yang menerapkan bunga. Menurut mereka bila dalam keadaan terpaksa, maka hal yang tidak diperbolehkan menjadi diperbolehkan.

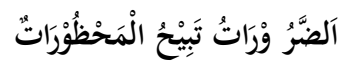

${ }^{24}$ Ismail, Perbankan Syariah (Jakarta: Kencana Media Group, 2010), 24.

25 Ibid., 
"Kondisi Dharurah akan memperbolehkan sesuatu yang semula dilarang" 26

Sedangkan kategori bunga yang diharamkan menurut $\mathrm{A}$ Hasan:

1. Mengandung paksaan, sesudah jatuh tempo nasabah dipaksa untuk membayar hutang atau menambah, sehingga nasabah tersebut terpaksa untuk membayar tambahan.

2. Mengandung sifat menyusahkan, bunga yang terlalu besar persentasenya membuat nasabah mengalami kesulitan untuk membayar hutangnya.

Bunga yang tidak diperbolehkan menurut pendapat Hasan adalah bunga yang bersifat konsumtif, yaitu bunga yang dipinjam oleh orang yang tidak mampu untuk memenuhi kebutuhan hidupnya. Kegiatan ekonomi masyarakat yang sesuai dengan ketentuan bunga yang tidak diperbolehkan adalah bank titil dan rentenir, karena kedua kegiatan tersebut mengunakan bunga yang persentasenya besar dan sebagian besar nasabahnya menggunakan bunga tersebut untuk kebutuhan konsumsi yang tidak menghasilkan, maka bunga yang ada tersebut semakin menambah beban nasabahnya. Bunga yang ada pada bank titil, rentenir dan simpan pinjam ini dalam padangan Islam juga tidak diperbolehkan.

Dari wawancara serta observasi yang telah dilakukan, kegiatan ekonomi (produksi dan konsumsi) masyarakat Sidomojo Krian Sidoarjo sudah sesuai dengan ekonomi secara Islami, karena sudah sesuai dengan ketentuan produksi dan konsumsi dalam Islam, tetapi kegiatan ekonomi tersebut berubah menjadi tidak sesuai dengan ekonomi Islam karena kesalahan dari sumber didapatkannya yaitu pinjaman yang mengandung bunga.

Sebagian masyarakat menganggap bahwa bunga diperbolehkan karena dalam keadaan darurat agar tercapai kemaslahatan, namun pada kenyataannya tidak semua nasabah mendapat mashlah\}at setelah melakukan pinjaman yang mengandung bunga. Terlebih bagi mereka yang menggunakan

\footnotetext{
${ }^{26}$ Maimoen Zubair, Formulasi Nalar Fiqh (Surabaya: Khalista, 2009), 223.
} 
pinjaman tersebut untuk memenuhi kebutuhan konsumtif. Kemaslahatan hanya dirasakan hanya diawal, untuk kedepannya mereka masih mengalami masalah bahkan dari pinjaman tersebut muncul masalah baru. Hal ini dapat dilihat dari hasil wawancara, dampak perekonomian yang dirasakan oleh tujuh belas nasabah setelah menggunakan pinjaman yang menerapkan bunga adalah enam orang mengalami dampak kemajuan pada ekonominya, lima tidak menggalami perubahan pada perekonomiannya dan enam orang lainnya merasa perekonomiannya semakin menurun setelah menggunakan pinjaman yang menggunakan bunga.

Keadaan ekonomi masyarakat memang dipengaruhi dari aktifitas ekonomi yang dilakukannya, namun bunga juga berperan dalam perekonomian masyarakat. Pinjaman yang menerapkan bunga yang terlalu besar dalam ekonomi tidak membantu masyarakat justru akan membuat ekonomi masyarakat melemah bahkan akan mengalami kerugian karena harus membayar bunga yang begitu besar.ss

Bunga tersebut dianggap mendzalimi karena bunga tersebut membuat nasabah merasa terbebani. Dengan adanya bunga tersebut maka hutang semakin bertambah. Khusunya bagi kalangan ekonomi menengah ke bawah yang menggunakan bunga tersebut untuk memenuhi kebutuhan sehari-hari mereka. Hal tersebut sesuai dengan firman Allah dalam Qs.An-Nissa'(4): 29.

"Hai orang-orang yang beriman, janganlah kamu saling memakan harta sesamamu dengan jalan yang batil, kecuali dengan jalan perniagaan yang Berlaku dengan suka samasuka di antara kamu. dan janganlah kamu membunuh dirimu Sesungguhnya Allah adalah Maha Penyayang kepadamu."27

\section{Penutup}

27 Ibid., 83. 
Berdasarkan pemaparan di atas, maka dapat disimpulkan bahwa tiga nasabah bank titil dan tiga nasabah rentenir berpandangan hukum bunga adalah haram. Meskipun demikian mereka tetap melakukan pinjaman di kedua tempat tersebut karena untuk memenuhi kebutuhan ekonomi, lima nasabah menggunakannya untuk kebutuhan konsumtif dan satu nasabah menggunakannya untuk kebutuhan produktif. Selain itu, prosedur pinjaman yang mudah menjadikan mereka memilih rentenir dan bank titil sebagai tempat meminjam, dan pada akhirnya tindakan tersebut tidak menjadikan ekonomi mereka menjadi lebih baik bahkan semakin memburuk karena setia minggu terbebani membayar cicilan beserta bunganya.

Pendapat mereka yang mengharamkan bunga bank telah sesuai dengan hukum Islam, sedangkan tindakan mereka meminjam melalui rentenir dan bank titil diperbolehkan asalkan dalam kondisi terpaksa sebagaimana kaidah "Kondisi Dharurah akan memperbolehkan sesuatu yang semula dilarang". Melihat ekonomi mereka yang tidak membaik setelah melakukan pinjaman melalui rentenir dan bank titil, maka selanjutnya hendaknya mereka tidak melakukan pinjaman di kedua tempat tersebut atau di tempat lain yang menerapkan bunga.

\section{Daftar Pustaka}

A. "Karyawan Bank Titil." Wawancara. November 23, 2013. Al-Jambi, Abu Muhammad Dwiono Koesen. Selamat Tinggal Bank Konvensional. Jakarta: Tifa Publishing House, 2013. Anik. "Nasabah Bank Titil." Wawancara. October 27, 2013. "Data Monografi Desa Sidomojo Krian Sidoarjo Tahun 2013," 2013.

H.R, Muhammad Nafik. Benarkah Bunga Haram? Surabaya: Amanah Pustaka, 2009.

Ikhwan, Wahyu. "Riba Dan Bunga Bank Perspektif Moh Hatta." UIN Sunan Kalijaga Yogyakarta, 2010.

Ismail. Perbankan Syariah. Jakarta: Kencana Media Group, 2010. 
Muslim, Muhammad Nur Ichwan. "Riba Dan Dampaknya," n.d. http://muslim.or.id/fiqh-dan-muamalah/riba-dandampaknya-2.html/comment-page-2, di akses pada hari selasa tanggal 22 oktober 2013, pukul13:12.

Muthahhari, Murtadha. Pandangan Islam Tentang Asuransi Dan Riba. Bandung: Pustaka Hidayah, 1995.

Rohmah, Evy Hidayatur. "Analisis Persepsi Dan Minat Masyarakat Terhadap Produk Talangan Haji Perbankan Syariah (Study Kasus Kecamatan Panceng)." UIN Sunan Ampel Surabaya, 2013.

Siamat, Dahlan. Manajemen Lembaga Keuangan. Jakarta: CV Intermedia, 1995.

Sugiarto, Aidi. "Fatwa MUI Tentang Bunga Bank (Studi Terhadap Masyarakat Malgi)." UIN Sunan Kalijaga Yogyakarta, 2008.

Sum. "Nasabah Rentenir." Wawancara. November 23, 2013.

Susi. "Nasabah Rentenir." Wawancara. December 4, 2013.

Tum. "Nasabah Bank Titil." Wawancara. November 27, 2013.

Wahyuni, Sri. "Nasabah Rentenir." Wawancara. October 11, 2013.

Warti. "Nasabah Bank Titil." Wawancara. November 27, 2013.

Zubair, Maimoen. Formulasi Nalar Fiqh. Surabaya: Khalista, 2009. 